\title{
Metode Dempster-Shafer untuk Diagnosis Dini Jenis Penyakit Gangguan Jiwa Skizofrenia Berbasis Sistem Pakar
}

\author{
${ }^{1 *}$ Hairani Hairani*, ${ }^{2}$ Kurniawan Kurniawan, ${ }^{3}$ Kurniadin Abd Latif, ${ }^{4}$ Muhammad Innuddin \\ ${ }^{1,2}$ ilmu Komputer, Fakultas Teknik Dan Desain, Universitas Bumigora \\ ${ }^{3}$ Rekayasa Perangkat Lunak, Fakultas Teknik Dan Desain, Universitas Bumigora, \\ ${ }^{4}$ Sistem Informasi, Fakultas Teknik Dan Desain, Universitas Bumigora, \\ Jl. Ismail Marzuki No.22, Cilinaya, Kec. Cakranegara, Kota Mataram, Nusa Tenggara Barat. 83127 \\ *Email: hairani@universitasbumigora.ac.id
}

(received: 21 Desember 2020, revised: 4 Februari 2021, accepted: 30 Maret 2021)

\begin{abstract}
Abstrak
Skizofrenia merupakan jenis gangguan jiwa bersifat kronis yang mempengaruhi proses berpikir, merasakan, dan berprilaku baik bagi penderitanya. Permasalahan selama ini adalah sebagian masyarakat umum merasa malu untuk melakukan pemeriksaan langsung ke rumah sakit kejiwaan, karena masih ada stigma negatif masyarakat. Tidak hanya itu, biaya konsultasi dengan dokter spesialis kejiwaan yang tidak murah menjadi salah satu faktor untuk tidak memeriksakan dirinya. Padahal deteksi dini jenis skizofrenia sangat diperlukan agar diberikan penaganan cepat dan tepat, sehingga minimalisir terjadinya kondisi yang lebih parah. Solusinya adalah menggunakan konsep sistem pakar menggunakan metode dempster shafer untuk diagnosis jenis penyakit skizofrenia. Tahapan penelitian ini terdiri dari akuisisi pengetahuan, perancangan tabel keputusan, implementasi, dan pengujian akurasi. Pengembangan sistem pakar diagnosis penyakit skizofrenia menggunakan metode dempster shafer untuk memudahkan masyarakat umum (pasien) untuk mengetahui jenis penyakit skizofrenia yang diderita beserta tingkat keyakinannya tanpa harus pergi ke dokter spesialis kejiwaan. Berdasarkan hasil pengujian yang telah dilakukan menggunakan 12 data, metode dempster shafer mendapatkan akurasi $100 \%$. Dengan demikian, metode dempster shafer dapat digunakan untuk diagnosis jenis penyakit skizofrenia.
\end{abstract}

Kata Kunci: Dempster Shafer, Skizofrenia, Sistem Pakar

\begin{abstract}
Schizophrenia is a type of chronic mental disorder that affects the sufferer's thinking, feeling, and behavior processes. The problem so far is that some of general public feel ashamed to conduct a direct examination at a mental hospital, because there is still a negative stigma from the community. Not only that, cost of consulting with a psychiatric specialist is not cheap to be a factor for not having him checked out. In fact, early detection of this type of schizophrenia is needed so that it is given fast and precise treatment, so as to minimize the occurrence of more severe conditions. The solution is to use the concept of an expert system using dempster shafer method for diagnosis of schizophrenia. The stages of this research consisted of knowledge acquisition, decision table design, implementation, and accuracy testing. Development of an expert system for diagnosing schizophrenia using dempster shafer method to make it easier for the general public (patients) to find out type of schizophrenia that is being suffered and their level of confidence without having to go to a psychiatric specialist. Based on the results of tests that have been carried out using 12 data, dempster shafer method gets 100\% accuracy. Thus, dempster shafer method can be used for diagnosis of schizophrenia.
\end{abstract}

Keywords: Dempster Shafer, Skizofrenia, Expert System

\section{Pendahuluan}

Skizofrenia merupakan jenis gangguan jiwa bersifat kronis yang mempengaruhi proses berpikir, merasakan, dan berprilaku baik bagi penderitanya. Akibatnya, penderita skizofrenia sulit berpikir jernih, kesulitan manajemen emosi, dan kesulitan bersosialisasi dengan orang lain. Tidak hanya itu, penderita skizofrenia juga sulit membedakan antara kenyataan dan hayalan. Kasus penderita 
skizofrenia di Nusa Tenggara Barat (NTB) berdasarkan data rumah sakit jiwa Mutiara sukma tahun 2018 dan 2019. Tahun 2018 terjadi 7184 kasus dan tahun 2019 terdapat 13129 kasus, terjadi kenaikan 5945 atau $45 \%$ pada tahun 2019.

Permasalahan selama ini adalah sebagian masyarakat umum merasa malu untuk melakukan pemeriksaan langsung ke rumah sakit kejiwaan karena masih ada stigma negatif masyarakat. Tidak hanya itu, biaya konsultasi dengan dokter spesialis kejiwaan yang tidak murah menjadi salah satu faktor untuk tidak memeriksakan dirinya. Padahal deteksi dini jenis skizofrenia sangat diperlukan agar diberikan penaganan cepat dan tepat, sehingga minimalisir terjadinya kondisi yang lebih parah. Solusi yang ditawarkan pada penelitian ini adalah menggunakan pendekatan sistem pakar. Sistem pakar merupakan pemindahan pengetahuan ahli ke komputer untuk menyelesaikan permasalahan tertentu.

Beberapa penelitian sebelumnya yang meneliti tentang diagnosis penyakit gangguan jiwa skizofrenia berbasis sistem pakar menggunakan berbagai metode diantaranya adalah metode Forward Chaining dan Certainty Factor [1], Certainty Factor [2]-[6], Dempster Shafer [7]-[10], Naïve Bayes[11][12],Penalaran Berbasis Kasus [13], dan Fuzzy Tsukamoto[14].

Berdasarkan kajian penelitian sebelumnya, ada persamaan dan perbedaan penelitian yang dilakukan. Persamaannya adalah terletak pada diagnosis penyakit skizofrenia dengan menggunakan metode yang sama yaitu metode Dempster Shafer. Adapun perbedaannya adalah terletak jumlah penyakit dan gejala yang digunakan serta pengujian kinerja metodenya. Pada penelitian ini menggunakan 6 jenis penyakit dan 43 gejala skizofrenia dan juga sekaligus melakukan pengujian kinerja metodenya berdasarkan akurasinya. Tujuan dari penelitian ini adalah mengembangkan sistem pakar diagnosis jenis penyakit skizofrenia menggunakan metode dempster shafer berbasis web yang memudahkan masyarakat umum untuk mengetahui jenis penyakit skizofrenia yang diderita secara dini.

\section{Tinjauan Pustaka}

Beberapa penelitian serupa yang sudah dilakukan sebelumnya diantaranya Penelitian [15][16] melakukan diagnosis penyakit rematik menggunakan metode Forward Chaining dan Faktor Kepastian. penelitian [9] melakukan diagnosis penyakit gangguan jiwa menggunakan metode Dhamster Shafer dengan 6 jenis penyakit gangguan jiwa. Kelemahan penelitian tersebut tidak menyebutkan jumlah gejala yang digunakan dan tidak melakukan pengujian akurasi metodenya. Penelitian [10] melakukan diagnosis penyakit mental menggunakan metode Dempster Shafer dengan 2 jenis penyakit dan 29 gejala. Kelemahan penelitian tersebut tidak melakukan pengujian kinerja metode yang digunakan. Penelitian [17] melakukan diagnosis penyakit skizofrenia menggunakan metode Bayesian Network dengan 6 jenis penyakit. Kelemahan penelitian tersebut, tidak menyebutkan jumlah gejala yang digunakan.

Penelitian [4] melakukan diagnosis penyakit mental dengan 5 jenis penyakit dan 24 gejala menggunakan metode faktor kepastian. Kelemahan penelitian tersebut, tidak melakukan pengujian kinerja metode yang digunakan. Penelitian [3] melakukan diagnosis penyakit mental menggunakan metode Faktor Kepastian. Kelemahan penelitian tersebut tidak menyebutkan jumlah penyakit dan gejala yang digunakan. Kelemahan lainnya adalah tidak melakukan pengujian kinerja metode yang digunakan. Penelitian [11] melakukan diagnosis penyakit gangguan jiwa menggunakan metode Teorema Bayes dengan 9 penyakit dan 19 gejala. Kelemahan penelitiannya adalah tidak melakukan pengujian kinerja metodenya. Penelitian [2] melakukan diagnosis penyakit kejiwaan dengan metode Faktor Kepastian. Kelemahan penelitian tersebut tidak menyebutkan jumlah penyakit dan gejala yang digunakan. Kelemahan lainnya adalah tidak melakukan pengujian kinerja metodenya.

Berdasarkan kajian penelitian sebelumnya, ada persamaan dan perbedaan penelitian yang dilakukan. Persamaannya adalah terletak pada diagnosis penyakit skizofrenia dengan menggunakan metode yang sama yaitu metode Dempster Shafer. Adapun perbedaannya adalah terletak jumlah penyakit dan gejala yang digunakan serta pengujian kinerja metodenya. Pada penelitian ini menggunakan 6 jenis penyakit dan 43 gejala skizofrenia dan juga sekaligus melakukan pengujian kinerja metodenya berdasarkan akurasi dengan cara membandingkan hasil diagnosa sistem dengan pakar. Adapun proses diagnosis penyakit skizofrenia menggunakan metode Dempster Shafer pada penelitian ini berdasarkan penelitian [18]. 


\section{Metode Penelitian}

Penelitian ini terdiri dari akuisisi pegetahuan, perancangan representasi pengetahuan, implementasi, dan pengujian akurasi.

\subsection{Akuisisi Pengetahuan}

Tahapan pertama adalah akuisisi pengetahuan. Data pengetahuan yang digunakan adalah jenis penyakit skizofrenia beserta gejalanya yang diperoleh dari hasil wawancara dengan dokter spesialis kejiwaan dr. H. I Putu Diatmika, Sp.KJ.

\subsection{Perancangan Representasi Pengetahuan}

Pada tahapan kedua adalah perancangan representasi pengetahuan yang digunakan untuk memodelkan data hasil akuisisi pengetahuan dalam bentuk tabel keputusan.

\subsection{Implementasi}

Pada tahapan ketiga adalah implementasi yang digunakan untuk membuat aplikasi sistem pakar diagnosis dini penyakit gangguan jiwa skizofrenia mengguanakan metode Demspter Shafer berbasis web dengan bahasa pemrograman PHP dan Mysql.

\subsection{Pengujian Kinerja}

Pada tahapan terakhir pada penelitian ini adalah pengujian kinerja. Pengujian kinerja digunakan untuk mengetahui tingkat ketepatan atau akurasi metode Dempster Shafer diagnosis jenis penyakit skizofrenia.

\section{Hasil dan Pembahasan}

\subsection{Akuisisi Pengetahuan}

Data pengetahuan yang digunakan adalah jenis penyakit skizofrenia beserta gejalanya yang diperoleh dari hasil wawancara dengan dokter spesialis kejiwaan dr. H. I Putu Diatmika, Sp.KJ. adapun jenis penyakit skizofrenia dan gejalanya ditunjukkan pada Tabel 1 dan Tabel 2.

Tabel 1. Jenis Penyakit Skizofrenia

\begin{tabular}{cl}
\hline Kode & Nama Penyakit \\
\hline P1 & Paranoid \\
P2 & Heberfrenik \\
P3 & Katatonik \\
P4 & Simpleks \\
P5 & Depresi Pasca-Skizofrenia \\
P6 & Residual \\
\hline
\end{tabular}

Tabel 2. Gejala Skizofrenia

\begin{tabular}{cl}
\hline Kode & Nama Penyakit \\
\hline G1 & $\begin{array}{l}\text { isi pikiran dirinya sendiri yang berulang atau bergema dalam kepala (tidak } \\
\text { keras) }\end{array}$ \\
G2 & isi pikiran asing dari luar masuk kedalam pikiran \\
G3 & isi pikiran diambil diambil keluar oleh sesuatu dari luar \\
G4 & isi pikiran tersiar keluar sehingga orang umum mengetahui \\
G5 & merasa diri dikendalikan oleh suatu kekuatan tertentu dai luar \\
G6 & merasa diri dipengaruhi oleh suatu kekuatan tertentu dai luar \\
G7 & merasa diri tidak berdaya dan pasrah terhadap suatu kekuatan dari luar \\
G8 & merasa diri memiliki mukzijat \\
G9 & berhalusinasi mendengar suara komentar terus menerus terhadap perilaku diri \\
G10 & mendengar jenis suara halusinasi lain yangberasal dari salah satu bagian tubuh \\
G11 & meyakini bahwa diri bisa berbicara dengan mahluk dari dunia lain \\
G12 & meyakini bahwa diri bisa mengendalikan cuaca \\
G13 & arus pikiran terputus yang mengakibatkan pembicaraan yang tidak relevan \\
G14 & merasa gaduh gelisah \\
G15 & sikap yang sangat apatis \\
\hline
\end{tabular}




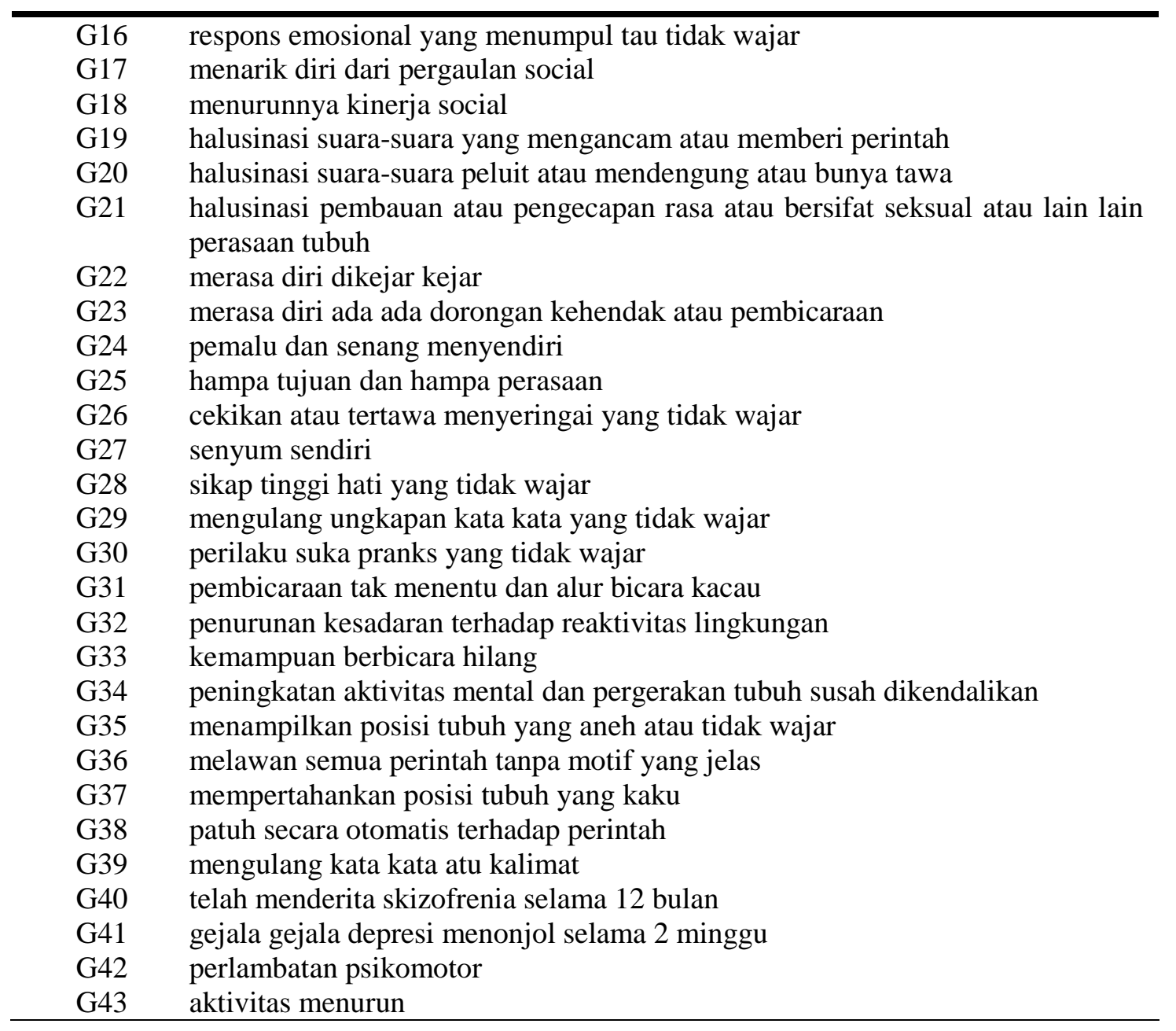

\subsection{Perancangan Representasi Pengetahuan}

Dari hasil akusisi data pada tahapan pertama, akan dimodelkan dalam bentuk tabel keputusan. Tabel keputusan digunakan untuk mengelompokan gejala untuk setiap penyakitnya yang ditunjukkan pada Tabel 3.

Tabel 3. Tabel Keputusan Diagnosis Penyakit Skizofrenia

\begin{tabular}{|c|c|c|c|c|c|c|c|}
\hline \multirow{2}{*}{$\begin{array}{c}\text { Kode } \\
\text { Gejala }\end{array}$} & \multicolumn{6}{|c|}{ Kode Penyakit } & \multirow[b]{2}{*}{ Bobot } \\
\hline & P1 & $\mathbf{P 2}$ & P3 & P4 & P5 & P6 & \\
\hline G1 & $\sqrt{ }$ & $\sqrt{ }$ & $\sqrt{ }$ & $\sqrt{ }$ & $\sqrt{ }$ & $\sqrt{ }$ & 0.85 \\
\hline G2 & $\sqrt{ }$ & & $\sqrt{ }$ & & & & 0.85 \\
\hline G3 & $\sqrt{ }$ & & & & & & 0.5 \\
\hline G4 & $\sqrt{ }$ & & & & & & 0.5 \\
\hline G5 & & & $\sqrt{ }$ & & & & 0.85 \\
\hline G6 & $\sqrt{ }$ & & $\sqrt{ }$ & & & & 0.5 \\
\hline G7 & $\sqrt{ }$ & & $\sqrt{ }$ & $\sqrt{ }$ & & & 0.5 \\
\hline G8 & $\sqrt{ }$ & & & & & & 0.25 \\
\hline G9 & $\sqrt{ }$ & & $\sqrt{ }$ & & & & 0.85 \\
\hline G10 & $\sqrt{ }$ & $\sqrt{ }$ & $\sqrt{ }$ & $\sqrt{ }$ & $\sqrt{ }$ & $\sqrt{ }$ & 0.5 \\
\hline G11 & & $\sqrt{ }$ & & $\sqrt{ }$ & & & 0.5 \\
\hline G12 & & $\sqrt{ }$ & & $\sqrt{ }$ & & & 0.5 \\
\hline G13 & & $\sqrt{ }$ & & $\sqrt{ }$ & & & 0.5 \\
\hline G14 & $\sqrt{ }$ & $\sqrt{ }$ & $\sqrt{ }$ & & & & 0.85 \\
\hline G15 & & $\sqrt{ }$ & $\sqrt{ }$ & & & & 0.5 \\
\hline G16 & & $\sqrt{ }$ & & $\sqrt{ }$ & & $\sqrt{ }$ & 0.5 \\
\hline G17 & & $\sqrt{ }$ & & $\sqrt{ }$ & $\sqrt{ }$ & $\sqrt{ }$ & 0.85 \\
\hline
\end{tabular}




\begin{tabular}{|c|c|c|c|c|c|c|c|}
\hline G18 & $\sqrt{ }$ & $\sqrt{ }$ & $\sqrt{ }$ & $\sqrt{ }$ & $\sqrt{ }$ & $\sqrt{ }$ & 0.5 \\
\hline G19 & $\sqrt{ }$ & & & & & & 0.85 \\
\hline G20 & $\sqrt{ }$ & & & & & & 0.5 \\
\hline $\mathrm{G} 21$ & $\sqrt{ }$ & & & & & & 0.85 \\
\hline $\mathrm{G} 22$ & $\sqrt{ }$ & & & & & & 1 \\
\hline $\mathrm{G} 23$ & $\sqrt{ }$ & & & & & & 1 \\
\hline $\mathrm{G} 24$ & & $\sqrt{ }$ & & $\sqrt{ }$ & & $\sqrt{ }$ & 0.5 \\
\hline $\mathrm{G} 25$ & & $\sqrt{ }$ & & & & $\sqrt{ }$ & 0.85 \\
\hline G26 & & $\sqrt{ }$ & & & & & 0.85 \\
\hline G27 & & $\sqrt{ }$ & & $\sqrt{ }$ & & $\sqrt{ }$ & 0.85 \\
\hline G28 & & $\sqrt{ }$ & & & & & 0.85 \\
\hline $\mathrm{G} 29$ & & $\sqrt{ }$ & & $\sqrt{ }$ & & & 0.85 \\
\hline G30 & & $\sqrt{ }$ & & & & & 0.85 \\
\hline G31 & & $\sqrt{ }$ & & $\sqrt{ }$ & & & 0.5 \\
\hline G32 & & $\sqrt{ }$ & $\sqrt{ }$ & & & & 0.5 \\
\hline G33 & & & $\sqrt{ }$ & $\sqrt{ }$ & & $\sqrt{ }$ & 0.85 \\
\hline G34 & & & $\sqrt{ }$ & & & & 0.85 \\
\hline G35 & & & $\sqrt{ }$ & & & & 0.85 \\
\hline G36 & & & $\sqrt{ }$ & & & & 0.85 \\
\hline G37 & & & $\sqrt{ }$ & & & & 0.85 \\
\hline G38 & & & $\sqrt{ }$ & & & & 0.85 \\
\hline G39 & & $\sqrt{ }$ & $\sqrt{ }$ & & & & 0.85 \\
\hline G40 & & & & & $\sqrt{ }$ & & 0.85 \\
\hline G41 & & & & & $\sqrt{ }$ & & 0.85 \\
\hline G42 & $\sqrt{ }$ & & $\sqrt{ }$ & & $\sqrt{ }$ & $\sqrt{ }$ & 0.85 \\
\hline G43 & $\sqrt{ }$ & & $\sqrt{ }$ & & $\sqrt{ }$ & $\sqrt{ }$ & 0.85 \\
\hline
\end{tabular}

\subsection{Implementasi}

Proses diagnosis penyakit skizofrenia diawali dengan input gejala yang dialami oleh pengguna (pasien). Beberapa gejala yang di masukkan akan dihitung menggunakan metode dampster shafer berdasarkan bobotnya masing-masing. Hasil diagnosis jenis penyakit skizofrenia yang dialami oleh pasien berdasarkan nilai densitas terbesar. Sebagai contoh kasus pengujian untuk proses diagnosis berdasarkan identifikasi dengan gejala seperti yang ditunjukkan pada Tabel 4.

Tabel 4. Kasus Pengujian

\begin{tabular}{clclc}
\hline $\begin{array}{c}\text { Kode } \\
\text { Gejala }\end{array}$ & \multicolumn{1}{c}{ Gejala } & $\begin{array}{c}\text { Kode } \\
\text { Penyakit }\end{array}$ & $\begin{array}{c}\text { Nama } \\
\text { Penyakit }\end{array}$ & Bobot \\
\hline G2 & isi pikiran asing dari luar masuk kedalam pikiran & P1 & $\begin{array}{l}\text { Paranoid } \\
\text { Katatonik }\end{array}$ & 0.85 \\
& P3 & P1 & Paranoid & 0.5 \\
G3 & $\begin{array}{l}\text { isi pikiran diambil diambil keluar oleh sesuatu } \\
\text { dari luar }\end{array}$ & P1 & Paranoid & 0.5 \\
G4 & $\begin{array}{l}\text { isi pikiran tersiar keluar sehingga orang umum } \\
\text { mengetahui }\end{array}$ & P1 & Paranoid & 0.5 \\
G6 & $\begin{array}{l}\text { merasa diri dipengaruhi oleh suatu kekuatan } \\
\text { tertentu dai luar }\end{array}$ & P3 & Katatonik & \\
& $\begin{array}{l}\text { P1 } \\
\text { G7 }\end{array}$ & merasa diri tidak berdaya dan pasrah terhadap & Paranoid & 0.5 \\
& suatu kekuatan dari luar & P3 & $\begin{array}{l}\text { Katatonik } \\
\text { Simpleks }\end{array}$ & \\
\hline
\end{tabular}

Proses diagnosis penyakit Skezofrenia dengan perhitungan manual menggunakan metode Dempster-Shafer sebagai berikut:

1. Gejala G2 : isi pikiran asing dari luar masuk kedalam pikiran 


$$
\begin{gathered}
m_{1}\{P 1, P 3\}=\frac{0.85}{1}=0.85 \\
m_{1}\{\theta\}=1-0.85=0.15
\end{gathered}
$$

2. Gejala G3 : isi pikiran diambil diambil keluar oleh sesuatu dari luar

$$
\begin{gathered}
m_{1}\{P 1\}=\frac{0.5}{1}=0.5 \\
m_{1}\{\theta\}=1-0.5=0.5
\end{gathered}
$$

Tabel 5. Aturan Kombinasi $m_{3}$

\begin{tabular}{ccc}
\hline$m_{1}$ & \multicolumn{2}{c}{$m_{2}$} \\
\cline { 2 - 3 } & $m_{2}\{P 1\}=0.5$ & $m_{2}\{\theta\}=0.5$ \\
\hline$m_{1}\{P 1, P 3\}=0.85$ & $\{P 1\}=0.85 * 0.5=0.425$ & $\{P 1, P 3\}=0.85 * 0.5=0.425$ \\
$\cdot$ & $\{P 1\}=0.5 * 0.15=0.075$ & $\{\theta\}=0.15 * 0.5=0.075$ \\
$m_{1}\{\theta\}=0.15$ & $\{P 15=0$ \\
\hline
\end{tabular}

Sehingga $m_{3}$ dapat dihitung dengan:

$$
\begin{gathered}
m_{3}\{P 1\}=\frac{0.425+0.075}{1-0}=0.5 \\
m_{3}\{P 1, P 3\}=\frac{0.425}{1-0}=0.425 \\
m_{3}\{\theta\}=\frac{0.075}{1-0}=0.075
\end{gathered}
$$

3. Gejala G4 : Isi pikiran tersiar keluar sehingga orang umum mengetahui

$$
\begin{aligned}
& m_{4}\{P 1\}=\frac{0.5}{1-0}=0.5 \\
& m_{4}\{\theta\}=1-0.5=0.5
\end{aligned}
$$

Tabel 6. Aturan Kombinasi $m_{5}$

\begin{tabular}{ccc}
\hline \multirow{2}{*}{$m_{3}$} & \multicolumn{2}{c}{$m_{4}$} \\
\cline { 2 - 3 } & \multicolumn{1}{c}{$m_{4}\{P 1\}=0.5$} & $m_{4}\{\theta\}=0.5$ \\
\hline$m_{3}\{P 1\}=0.5$ & $\{P 1\}=0.5 * 0.5=0.25$ & $\{P 1\}=0.5 * 0.5=0.25$ \\
$m_{3}\{P 1, P 3\}=0.425$ & $\{P 1\}=0.425 * 0.5=0.2125$ & $\{P 1, P 3\}=0.425 * 0.5=0.2125$ \\
$\cdot$ & $\{P 1\}=0.5 * 0.075=0.0375$ & $\{\theta\}=0.5 * 0.075=0.0375$ \\
$m_{3}\{\theta\}=0.075$ & &
\end{tabular}

Sehingga $m_{5}$ dapat dihitung dengan:

$$
\begin{gathered}
m_{5}\{P 1\}=\frac{0.25+0.2125+0.0375+0.25}{1-0}=0.75 \\
m_{5}\{P 1, P 3\}=\frac{0.2125}{1-0}=0.2125 \\
m_{5}\{\theta\}=\frac{0.0375}{1-0}=0.0375
\end{gathered}
$$

4. Gejala G6 : Merasa diri dipengaruhi oleh suatu kekuatan tertentu dari luar 


$$
\begin{gathered}
m_{6}\{P 1, P 3\}=\frac{0.5}{1-0}=0.5 \\
m_{6}\{\theta\}=1-0.5=0.5
\end{gathered}
$$

Tabel 7. Aturan Kombinasi $m_{7}$

\begin{tabular}{ccc}
\hline$m_{5}$ & \multicolumn{2}{c}{$m_{6}$} \\
\cline { 2 - 3 } & \multicolumn{1}{c}{$m_{6}\{P 1, P 3\}=0.5$} & $m_{6}\{\theta\}=0.5$ \\
\hline$m_{5}\{P 1\}=0.75$ & $\{P 1\}=0.75 * 0.5=0.375$ & $\{P 1\}=0.75 * 0.5=0.375$ \\
$m_{5}\{P 1, P 3\}=0.2125$ & $\{P 1, P 3\}=0.2125 * 0.5=0.10625$ & $\{P 1, P 3\}=0.2125 * 0.5=0.10625$ \\
$\cdot$ & & \\
$m_{3}\{\theta\}=0.0375$ & $\{P 1, P 3\}=0.5 * 0.0375=0.01875$ & $\{\theta\}=0.5 * 0.0375=0.01875$ \\
\hline
\end{tabular}

Sehingga $m_{7}$ dapat dihitung dengan:

$$
\begin{gathered}
m_{7}\{P 1\}=\frac{0.375+0.375}{1-0}=0.75 \\
m_{7}\{P 1, P 3\}=\frac{0.10625+0.10625+0.01875}{1-0}=0.23125 \\
m_{5}\{\theta\}=\frac{0.0375}{1-0}=0.01875
\end{gathered}
$$

5. Gejala G7 : Merasa diri tidak berdaya dan pasrah terhadap suatu kekuatan dari luar

$$
\begin{gathered}
m_{8}\{P 1, P 3, P 4\}=\frac{0.5}{1-0}=0.5 \\
m_{8}\{\theta\}=1-0.5=0.5
\end{gathered}
$$

Tabel 8. Aturan Kombinasi $m_{9}$

\begin{tabular}{ccc}
\hline$m_{7}$ & \multicolumn{2}{c}{$m_{8}$} \\
\cline { 2 - 3 } & $m_{8}\{P 1, P 3, P 4\}=0.5$ & $m_{8}\{\theta\}=0.5$ \\
\hline$m_{7}\{P 1\}=0.75$ & $\{P 1\}=0.75 * 0.5=0.375$ & $\{P 1\}=0.75 * 0.5=0.375$ \\
$m_{7}\{P 1, P 3\}=0.23125\{P 1, P 3\}=0.23125 * 0.5=0.115625$ & $\{P 1, P 3\}=0.23125 * 0.5=0.115625$ \\
$\cdot m_{7}\{\theta\}=0.01875$ & $\{P 1, P 3, P 4\}=0.5 * 0.01875=0.00937\{9\}=0.5 * 0.01875=0.009375$ \\
\hline
\end{tabular}

Sehingga $m_{9}$ dapat dihitung dengan:

$$
\begin{gathered}
m_{9}\{P 1\}=\frac{0.375+0.375}{1-0}=0.75 \\
m_{9}\{P 1, P 3\}=\frac{0.115625+0.115625}{1-0}=0.23125 \\
m_{9}\{\theta\}=\frac{0.009375}{1-0}=0.009375
\end{gathered}
$$


Berdasarkan hasil perhitungan manualnya, dapat disimpulkan bahwa Pasien 1 mengalami penyakit Skizofrenia Jenis Paranoid dengan nilai kepercayaan 0.75 atau $75 \%$.

Adapun dengan menggunakan sistem yang dikembangkan menggunakan Bahasa pemrograman PHP dan Mysql untuk dilakukan pengujian diagnosa berdasarkan gejala yang sama dengan perhitungan manualnya, dapat ditunjukkan pada Gambar 1.

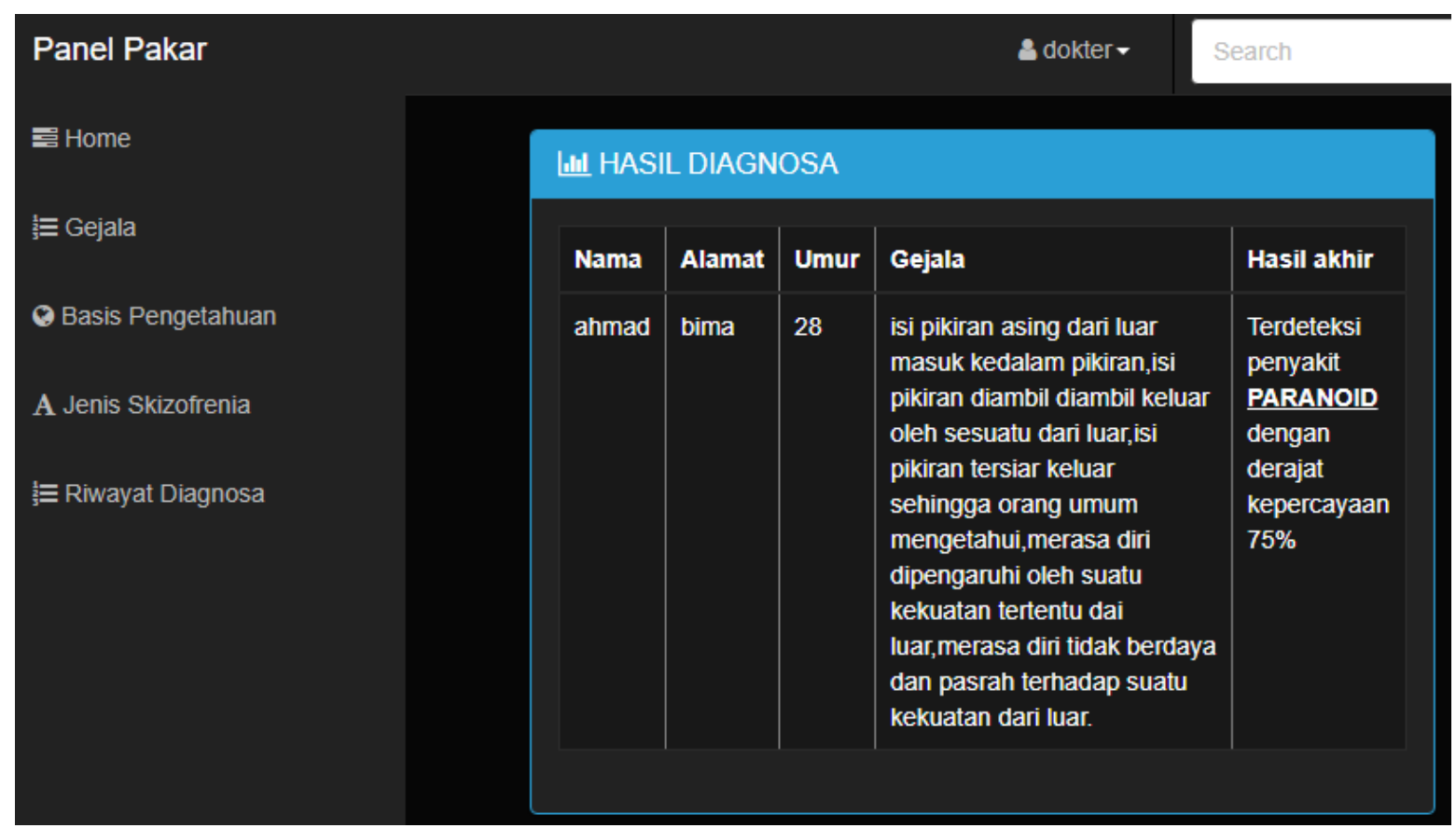

Gambar 1. Hasil Diagnosis Sistem

Berdasarkan validasi hasil diagnosis penyakit Skizofrenia dengan gejala G2, G3, G4, G6, dan G7 dengan perhitungan manual dan menggunakan sistem memiliki hasil diagnosis yang sama yaitu penyakit Skizofrenia Paranoid dengan derajat kepercayaan $75 \%$.

\subsection{Pengujian Kinerja}

Untuk melihat kinerja dari metode yang digunakan, maka penelitian ini melakukan pengujian menggunakan 12 data ditunjukkan pada Tabel 9.

\section{Tabel 9. Hasil Pengujian Akurasi}

\begin{tabular}{clccc}
\hline No & \multicolumn{1}{c}{ Kasus } & Hasil Sisten & Hasil Pakar & Keterangan \\
\hline 1. & G1, G2, G3, G4 & Paranoid & Paranoid & Sesuai \\
2. & G5, G6, G7, G9, G10 & Katatonik & Katatonik & Sesuai \\
3. & G10, G11, G12, G13, G14, G15 & Hebefrenik & Hebefrenik & Sesuai \\
4. & G14, G15, G16, G17, G18 & Hebefrenik & Hebefrenik & Sesuai \\
5. & G7, G10, G17, G18, G24, G27, G29, G31, G33 & Simpleks & Simpleks & Sesuai \\
6. & G1, G10, G17, G18, G40, G41, G42, G43 & Depresi Pasca & Depresi Pasca & Sesuai \\
& & Skezofrenia & Skezofrenia & \\
7. & G16, G17, G18, G24, G25, G27, G33, G42, G43 & Residual & Residual & Sesuai \\
8. & G6, G9, G19, G26, G35 & Katatonik & Katatonik & Sesuai \\
9. & G6, G8, G13, G14, G19, G20, G33 & Paranoid & Paranoid & Sesuai \\
10. & G34, G35, G36, G37, G38 & Katatonik & Katatonik & Sesuai \\
11. G20, G21, G22, G23, G24, G25 & Paranoid & Paranoid & Sesuai \\
12. G1, G10, G20, G30, G39 & Hebefrenik & Hebefrenik & Sesuai
\end{tabular}

Berdasarkan Tabel 9 hasil nilai akurasi menggunakan metode Dempster-Shafer dapat dihitung menggnakan persamaan 1 . 


$$
\begin{gathered}
\text { Akurasi }=\frac{\text { Jumlah terdiagnosis tepat }}{\text { Total data }} * 100 \\
\text { Akurasi }=\frac{12}{12} * 100=100 \%
\end{gathered}
$$

Akurasi yang didapatkan metode Dempster-Shafer untuk diagnosis dini penyakit Skizofrenia adalah $100 \%$. Dengan demikian, dapat disimpulkan bahwa metode Dempster-Shafer sangat tepat digunakan untuk diagnosis dini penyakit Skizofrenia.

\section{Kesimpulan}

Pengembangan sistem pakar diagnosis penyakit skizofrenia menggunakan metode dempster shafer untuk memudahkan masyarakat umum (pasien) untuk mengetahui jenis penyakit skizofrenia yang diderita beserta tingkat keyakinannya tanpa harus pergi ke dokter spesialis kejiwaan. Berdasarkan hasil pengujian yang telah dilakukan menggunakan 12 data, metode dempster shafer mendapatkan akurasi $100 \%$. Dengan demikian, metode dempster shafer dapat digunakan untuk diagnosis jenis penyakit skizofrenia, karena memiliki kinerja sangat bagus. Untuk penelitian selanjutnya dapat metode hibrida dalam diagnosis penyakit skizofrenianya.

\section{Referensi}

[1] Windarsyah, Husnul Khatimi, and Ryan Maulana, "Sistem Pakar Diagnosa Jenis Gangguan Jiwa Skizofrenia Menggunakan Kombinasi Metode Forward Chaining Dan Certainty Factor," J. Teknol. Inf. Univ. Lambung Mangkurat, vol. 2, no. 2, pp. 51-58, 2017, doi: 10.20527/jtiulm.v2i2.20.

[2] F. I. Mevung et al., "Diagnosis Penyakit Kejiwaan Menggunakan Metode Certainty Factor," in Prosiding Seminar Ilmu Komputer dan Teknologi Informasi, 2017, vol. 2, no. 1, pp. 374-380.

[3] C. Susanto, "Aplikasi Sistem Pakar untuk Gangguan Mental pada Anak dengan Metode Certainty Factor," J. Pekomas, vol. 18, no. 1, pp. 27-36, 2015.

[4] G. V. G. Putri, "Sistem pakar diagnosa mental ilness sikosis dengan menggunakan metode certainty factor," J. Inovtek Polbeng - Seri Inform., vol. 3, no. 2, pp. 164-168, 2018.

[5] A. Suwarno, I. Husin, and U. E. Zenni, "Aplikasi Sistem Pakar Untuk Mendiagnosa Gangguan Kepribadian Pada Remaja Dengan Menggunakan Metode Certainty Factor (CF)," Kilat, vol. 8, no. 2, pp. 127-140, 2019, doi: 10.33322/kilat.v8i2.602.

[6] A. Muhammad, B. Hendrik, and R. Iswara, "Expert System Application for Diagnosing of Bipolar Disorder with Certainty Factor Method Based on Web and Android," J. Phys. Conf. Ser., vol. 1339, no. 1, pp. 1-12, 2019, doi: 10.1088/1742-6596/1339/1/012020.

[7] D. Hastari and F. Bimantoro, "Sistem Pakar untuk Mendiagnosis Gangguan Mental Anak Menggunakan Metode Dempster Shafer," J-Cosine, vol. 2, no. 2, pp. 71-79, 2018.

[8] D. J. Silvia Angelia Gozalia, "Metode Dempster Shafer Untuk Mendektesi Penyakit Mental Disosder:Skizofrenia Dan Psikotik," J. Simetrik, vol. 1, no. 2, pp. 105-109, 2019, [Online]. Available: http://journal.ummgl.ac.id/index.php/komtika/article/view/3701.

[9] L. Sudarmana and F. Lestari, "Aplikasi Sistem Pakar Untuk mendiagnosis Gangguan Jiwa Schizophrenia," J. Inform. Pengemb. IT, vol. 3, no. 1, pp. 40-44, 2018, [Online]. Available: http://ejournal.poltektegal.ac.id/index.php/informatika/article/view/650.

[10] A. Rahmadhani, F. Fauziah, and A. Aningsih, "Sistem Pakar Deteksi Dini Kesehatan Mental Menggunakan Metode Dempster-Shafer," Sisfotenika, vol. 10, no. 1, p. 37, 2020, doi: 10.30700/jst.v10i1.747.

[11] E. Zamroni and R. Arnie, "Sistem Pakar Diagnosa Penyakit Jiwa Menggunakan Theorema Bayes," PROGRESIF, vol. 12, no. 1, pp. 1517-1524, 2012.

[12] R. D. Wardhani, R. Regasari, M. Putri, and B. D. Setiawan, "Sistem Pakar Diagnosis Penyakit Schizophrenia Menggunakan Metode Bayesian Network," J. Pengemb. Teknol. Inf. dan Ilmu Komput., vol. 1, no. 11, pp. 1416-1424, 2017.

[13] R. Rahim, W. Purba, M. Khairani, and R. Rosmawati, "Online Expert System for Diagnosis 
Psychological Disorders Using Case-Based Reasoning Method," J. Phys. Conf. Ser., vol. 1381, no. 1, pp. 1-8, 2019, doi: 10.1088/1742-6596/1381/1/012044.

[14] O. D. Parwita, A. S. Sukamto, and R. D. Nyoto, "Sistem Pakar Diagnosis Penyakit Kejiwaan Skizofrenia Menggunakan Metode Tsukamoto," JUSTIN (Jurnal Sist. dan Teknol. Informasi), vol. 4, no. 2, pp. 246-251, 2016, [Online]. Available: https://jurnal.untan.ac.id/index.php/justin/article/view/13596.

[15] H. Hairani, M. N. Abdillah, and M. Innuddin, "Perancangan Sistem Pakar Diagnosis Penyakit Rematik Menggunakan Inferensi Forward Chaining Berbasis Prolog," InfoTekJar (Jurnal Nas. Inform. dan Teknol. Jaringan), vol. 4, no. 1, pp. 8-11, 2019, doi: 10.30743/infotekjar.v4i1.1377.

[16] H. Hairani, M. N. Abdillah, and M. Innuddin, "An Expert System for Diagnosis of Rheumatic Disease Types Using Forward Chaining Inference and Certainty Factor Method," in 2019 International Conference on Sustainable Information Engineering and Technology (SIET), 2019, pp. 104-109, doi: 10.1109/SIET48054.2019.8986035.

[17] N. Nurajijah and D. Riana, "Algoritma Naïve Bayes, Decision Tree, dan SVM untuk Klasifikasi Persetujuan Pembiayaan Nasabah Koperasi Syariah," J. Teknol. dan Sist. Komput., vol. 7, no. 2, p. 77, 2019, doi: 10.14710/jtsiskom.7.2.2019.77-82.

[18] E. P. Gunawan and R. Wardoyo, "An Expert System Using Certainty Factor for Determining Insomnia Acupoint," IJCCS (Indonesian J. Comput. Cybern. Syst., vol. 12, no. 2, p. 119, 2018, doi: 10.22146/ijccs.26328. 